\title{
Influence of Zinc and Boron in Residual Blackgram Productivity
}

\author{
M. Naveen Saviour ${ }^{1 *}$ and P. Stalin ${ }^{2}$ \\ ${ }^{1}$ Research Scholar, Department of Soil Science and Agricultural Chemistry, Tamil Nadu Agricultural University, \\ Coimbatore, Tamil Nadu, India-641003; agri_naveen@rediffmail.com \\ 2Professor (SS\&AC), Department of Soil Science and Agricultural ChemistryTamil Nadu Agricultural University, \\ Coimbatore, Tamil Nadu, India-641003; stalinpreemon@yahoo.com
}

\begin{abstract}
A field experiment was conducted on sandy loam soil to study the effect of applied zinc and boron to the residual blackgram in maize-blackgram cropping system during (2011-12) kharif season. There were three and nine levels of NPK as main treatments and $\mathrm{Zn}$ and $\mathrm{B}$ as sub plot treatments respectively. Results revealed that soil application of $\mathrm{ZnSO}_{4}$ and Borax @ $50 \mathrm{~kg}$ and $10 \mathrm{~kg} \mathrm{ha}^{-1}(\mathrm{~S} 8)$ respectively combined with recommended $100 \% \mathrm{NPK} \mathrm{ha}^{-1}$ to the proceeding crop, significantly recorded the highest dry pod $\left(690.3 \mathrm{~kg} \mathrm{ha}^{-1}\right)$ and haulm yield $\left(803.2 \mathrm{~kg} \mathrm{ha}^{-1}\right)$ with increase being 52.16 and $50.7 \%$ over control for the successive residual blackgram. The same treatment also greatly influenced the yield attributes viz., the highest number of pods plant ${ }^{-1}$ and 100 seed weight and found on par with treatment (S9).
\end{abstract}

Keywords: Blackgram, Boron, Cropping System, Residual, Yield, Zinc.

\section{Introduction}

Cropping system has attained great significance in intensified agriculture in India and experiments on cropping systems are the ultimate solution to overcome the drawbacks of mono-cropping system to exploit the soil intensively for enhanced food production. Sustaining the supply of deficient micronutrients along with macronutrients in appreciate amount and right proportion is a key to maximize productivity gains from macronutrients. India is used as an exclusive example to explicate the role of micronutrient play in optimum utilization of macronutrients [4]. By supplying plants with micronutrients, either through soil application, foliar spray, or seed treatment, increased yield and quality grains, as well as macronutrient use efficiency, could be achieved [5]. Among micronutrients, zinc and boron deficiency accounts about $49 \%$ and 33\% respectively in Indian soils, which reduce not only the yield but also the nutritional quality of the produce [8]. Zinc is involved in auxin formation, activation of dehydrogenase enzymes; stabilization of ribosomal fractions [3] and boron is very important in cell division, pod and seed formation [2]. Morever, these two nutrients are found to have its residual impact on the successive crops, it is imperative that application of $\mathrm{Zn}$ and B containing fertilizers are needed to exploit the production potential of crops under cropping systems and also to mitigate the deficiencies of these nutrients. Addition of $\mathrm{S}+\mathrm{Zn}+\mathrm{B}$ in balanced fertilization schedule increased $\mathrm{N}, \mathrm{P}$ and $\mathrm{K}$ utilization efficiency which highlights the role of micronutrients in increasing macronutrient use efficiency [9]. Since, maize and blackgram are the two important crops which are preferred much for its nutritional quality, a study was contemplated with soil application of various levels of zinc sulphate and borax along with major nutrients to enhance the productivity of residual blackgram in maize-blackgram cropping system.

${ }^{*}$ Corresponding author:

M. Naveen Saviour (agri_naveen@rediffmail.com) 


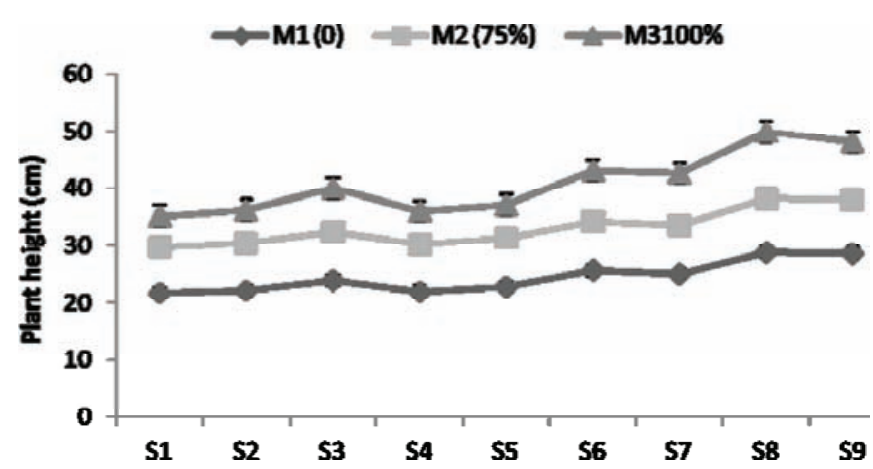

Figure 1. Effect of applied $\mathrm{Zn}$ and $\mathrm{B}$ on plant height $(\mathrm{cm})$ of residual blackgram.

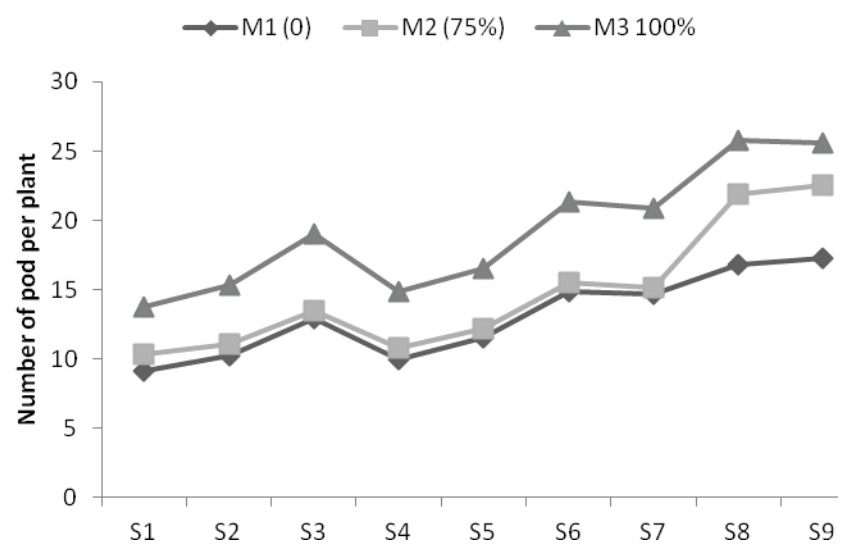

Figure 2. Effect of applied $\mathrm{Zn}$ and $\mathrm{B}$ on number of pods per plant of residual blackgram.

\section{Materials and Methods}

A field experiment was conducted during kharif(2011-12) to study the residual effect of applied $\mathrm{Zn}$ and $\mathrm{B}$ in succeeding blackgram under maize-blackgram cropping system in $\mathrm{B}$ and $\mathrm{Zn}$-deficient sandy loam soils (Fine loamy hyperthermic Ultic Haplustalfs) in Pudukkottai district, Tamil $\mathrm{Nadu}$. The treatments included for the main crop maize hybrid (NK-6240) and residual blackgram (var.VBN-3) were three levels of NPK as main plot treatments viz., $\mathrm{M}_{1}$ : Control (No N, P and K), $\mathrm{M}_{2}: 75 \%$ NPK kg ha ${ }^{-1}, \mathrm{M}_{3}: 100 \%$ NPK ha ${ }^{-1}(250: 75: 75)$ and nine levels of sub plot treatments as $\mathrm{ZnSO}_{4} @ 37.5 \mathrm{~kg} \mathrm{ha}^{-1}(\mathrm{~S} 2), 50 \mathrm{~kg} \mathrm{ZnSO}_{4} \mathrm{ha}^{-1}(\mathrm{~S} 3), 10 \mathrm{~kg}$ Borax ha ${ }^{-1}(\mathrm{~S} 4), 15 \mathrm{~kg}$ Borax ha-1 (S5), $37.5 \mathrm{~kg} \mathrm{ZnSO}_{4} \mathrm{ha}^{-1}$ $+10 \mathrm{~kg}$ Borax ha ${ }^{-1}(\mathrm{~S} 6), 37.5 \mathrm{~kg} \mathrm{ZnSO}_{4} \mathrm{ha}^{-1}+15 \mathrm{~kg}$ Borax $\mathrm{ha}^{-1}$ (S7), $50 \mathrm{~kg} \mathrm{ZnSO}_{4} \mathrm{ha}^{-1}+10 \mathrm{~kg}$ Borax ha $^{-1}(\mathrm{~S} 8)$ and 50 $\mathrm{kg} \mathrm{ZnSO}{ }_{4} \mathrm{ha}^{-1}+15 \mathrm{~kg}$ Borax ha ${ }^{-1}$ (S9) and also without application of fertilizers was maintained as absolute control (S1) in split plot design. Totally, 27 treatments replicated thrice imposed with fertilizer sources viz; urea $(46 \% \mathrm{~N})$,

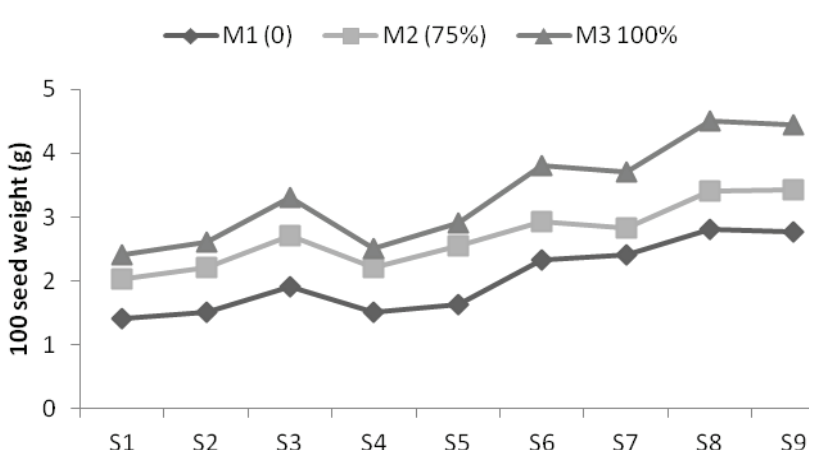

Figure 3. Effect of applied $\mathrm{Zn}$ and B on 100 seed weight (g) of residual blackgram.

super $(16 \% \mathrm{P})$, potash $(60 \% \mathrm{~K})$, zinc sulphate $(\mathrm{Zn}-21 \%)$, borax (B-11\%) and gypsum (18\% S). The experimental initial soil analysed for sandy clay loam in texture with pH: 6.42, EC: $0.06 \mathrm{dSm}^{-1}$. The organic carbon content of soil was 0.33 per cent with low in available $\mathrm{KMNO}_{4} \mathrm{~N}$ $\left(264 \mathrm{~kg} \mathrm{ha}^{-1}\right)$, medium in Olsen P $\left(15.4 \mathrm{~kg} \mathrm{ha}^{-1}\right)$ and high $\mathrm{NH}_{4} \mathrm{OAC} \mathrm{K}\left(222 \mathrm{~kg} \mathrm{ha}^{-1}\right)$. The DTPA extractable micronutrients viz., $\mathrm{Fe}\left(14.2 \mathrm{mg} \mathrm{kg}^{-1}\right), \mathrm{Mn}\left(8.3 \mathrm{mg} \mathrm{kg}^{-1}\right)$ and $\mathrm{Cu}$ $\left(1.37 \mathrm{mg} \mathrm{kg}^{-1}\right)$ were sufficient while DTPA $\mathrm{Zn}(0.84 \mathrm{mg}$ $\left.\mathrm{kg}^{-1}\right)$ and HWSB $\left(0.20 \mathrm{mg} \mathrm{kg}^{-1}\right)$ were deficient. The fertilizer requirement for maize and blackgram followed were 250:75:75 and 25:50:25 $\mathrm{kg} \mathrm{NPK} \mathrm{ha}^{-1}$ respectively. Uniform dose of S@ $40 \mathrm{~kg} \mathrm{ha}^{-1}$ for maize and $20 \mathrm{~kg} \mathrm{ha}^{-1}$ for successive black gram were applied to all treatment plots without disturbing the mail plot. Need based plant production and protection measures were taken up and the crops were grown to maturity and harvested. The yield and yield parameters were recorded during harvest stage of crop.

\section{Results and Discussion}

The data revealed that the effect of the applied micronutrients ( $\mathrm{Zn}$ and $\mathrm{B}$ ) greatly influenced the plant height and yield attributes viz., the highest number of pods plant ${ }^{-1}$ and 100 seed weight were graphically represented in Figures 1, 2 and 3. Application of $50 \mathrm{~kg} \mathrm{ZnSO}_{4} \mathrm{ha}^{-1}+10 \mathrm{~kg}$ Borax ha ${ }^{-1}$ along with $100 \%$ recommended NPK $\left(\mathrm{M}_{3} \mathrm{~S}_{8}\right)$ evidenced with plant height $(49.8 \mathrm{~cm})$ with $56.27 \%$ increased over control. The same treatment also, registered significantly with the highest number of pods plant ${ }^{-1}$ (25.8) and 100 seed weight $(4.50 \mathrm{~g})$ which was statistically on par with the treatment combination $\mathrm{M}_{3} \mathrm{~S}_{9}$. The lowest number of pods plant $^{-1}(9.1)$ and 100 seed weight $(1.41 \mathrm{~g})$ was registered in the absolute control. 
Table 1. Effect of applied zinc and boron on pod and haulm yield $\left(\mathrm{kg} \mathrm{ha}^{-1}\right)$ on residual black gram

\begin{tabular}{|c|c|c|c|c|c|c|c|c|c|c|}
\hline \multirow{3}{*}{$\begin{array}{l}\text { NPK levels } \\
\left(\mathrm{kg} \mathrm{ha}^{-1}\right)\end{array}$} & \multicolumn{10}{|c|}{ Micronutrients levels ( $\mathrm{Zn}$ and $\mathrm{B})\left(\mathrm{kg} \mathrm{ha}^{-1}\right)$} \\
\hline & \multicolumn{10}{|c|}{ Pod yield $\left(\mathrm{kg} \mathrm{ha}^{-1}\right)$} \\
\hline & $\begin{array}{c}\mathrm{S}_{1} \\
(\mathrm{Zn} 0 \mathrm{~B} 0)\end{array}$ & $\begin{array}{c}\mathrm{S}_{2} \\
(\mathrm{Zn} 37.5)\end{array}$ & $\begin{array}{c}\mathrm{S}_{3} \\
(\mathrm{Zn} 50)\end{array}$ & $\begin{array}{c}\mathrm{S}_{4} \\
(\mathrm{~B} 10)\end{array}$ & $\begin{array}{c}\mathrm{S}_{5} \\
(\mathrm{~B} 15)\end{array}$ & $\begin{array}{c}\mathrm{S}_{6} \\
(\mathrm{Zn} 37.5 \mathrm{~B} 10)\end{array}$ & $\begin{array}{c}\mathrm{S}_{7} \\
(\mathrm{Zn} 37.5 \mathrm{~B} 15)\end{array}$ & $\begin{array}{c}\mathrm{S}_{8} \\
(\mathrm{Zn} 50 \mathrm{~B} 10)\end{array}$ & $\begin{array}{c}\mathrm{S}_{9} \\
(\mathrm{Zn} 50 \mathrm{~B} 15)\end{array}$ & Mean \\
\hline$M_{1}(0)$ & 330.2 & 338.3 & 363.0 & 337.6 & 348.0 & 388.5 & 383.4 & 417.0 & 409.5 & 368.4 \\
\hline $\mathrm{M}_{2}(75 \%)$ & 365.1 & 375.1 & 417.5 & 371.2 & 399.1 & 451.4 & 443.2 & 558.5 & 541.7 & 435.9 \\
\hline$M_{3}(100 \%)$ & 425.3 & 436.3 & 498.5 & 436.1 & 458.5 & 561.3 & 555.2 & 750.3 & 725.1 & 538.5 \\
\hline Mean & 373.5 & 383.2 & 426.3 & 381.6 & 401.9 & 467.1 & 460.6 & 575.3 & 558.8 & 447.6 \\
\hline \multicolumn{11}{|c|}{ Haulm yield (kg ha-1) } \\
\hline$M_{1}(0)$ & 395.2 & 404.3 & 429.0 & 403.9 & 416.7 & 453.6 & 447.5 & 494.1 & 491.6 & 437.3 \\
\hline$M_{2}(75 \%)$ & 435.1 & 441.1 & 473.5 & 440.6 & 552.2 & 514.4 & 509.3 & 635.6 & 598.3 & 511.1 \\
\hline$M_{3}(100 \%)$ & 502.2 & 513.1 & 555.4 & 512.6 & 525.4 & 644.2 & 636.1 & 803.2 & 798.1 & 610.0 \\
\hline Mean & 444.2 & 452.8 & 486.0 & 452.4 & 498.1 & 537.4 & 531.0 & 644.3 & 629.3 & 519.5 \\
\hline \multicolumn{6}{|c|}{ Pod yield } & \multicolumn{5}{|c|}{ Haulm yield } \\
\hline & $\mathbf{M}$ & S & $\mathrm{M}$ a & & $\mathrm{S}$ at $\mathrm{M}$ & $\mathbf{M}$ & $\mathrm{S}$ & $M$ at $S$ & \multicolumn{2}{|c|}{$\mathrm{S}$ at $\mathrm{M}$} \\
\hline SEd & 3.58 & 7.14 & 12.0 & & 12.37 & 3.91 & 8.23 & 13.99 & \multicolumn{2}{|c|}{14.25} \\
\hline $\mathrm{CD}(0.05)$ & 9.94 & 14.36 & 25.3 & & 24.88 & 10.86 & 16.54 & 28.97 & \multicolumn{2}{|c|}{28.65} \\
\hline
\end{tabular}

Regarding yield, the pod and haulm yield ranged from 330.2 to $690.3 \mathrm{~kg} \mathrm{ha}^{-1}$ and 395.2 to $803.2 \mathrm{~kg} \mathrm{ha}^{-1}$ respectively. The significant increase in dry pod $\left(690.3 \mathrm{~kg} \mathrm{ha}^{-1}\right)$ and haulm yield $\left(803.2 \mathrm{~kg} \mathrm{ha}^{-1}\right)$ were recorded with the application of $50 \mathrm{~kg} \mathrm{ZnSO}_{4} \mathrm{ha}^{-1}+15 \mathrm{~kg}$ Borax ha ${ }^{-1}$ along with $100 \%$ recommended NPK $\left(\mathrm{M}_{3} \mathrm{~S}_{8}\right)$ which is statistically on par with the treatment combination $\mathrm{M}_{3} \mathrm{~S}_{9}$. The pod and haulm yield increase being 52.16 and $50.7 \%$ over control (Table 1). The lowest pod and haulm yield was registered in the absolute control $\left(330.2 \mathrm{~kg} \mathrm{ha}^{-1}\right.$ and $395.2 \mathrm{~kg} \mathrm{ha}^{-1}$ ) than the treatments enhanced with NPK or Zn and B or combined with NPK or Zn and B. The increased effect on yield attributes and yield maybe due to the combined effect of both $\mathrm{Zn}$ and $\mathrm{B}$ along with NPK which might have triggered the overall growth of the crop since the soil was deficient in $\mathrm{Zn}$ and B. Similar increase in growth and yield due to zinc application were also observed in rice-maize cropping system by Chandrapala et al. [1]. The data clearly suggested that addition of $\mathrm{Zn}$ and boron along with NPK had a significant response in terms of grain production. Similar results were reported by Poongothai and Chitdeshwari [7] and Subramanian et al. [10]. Patel et al. [6] highlighted the benefits of inclusion of leguminous crop in potato based cropping system. Sudarsan and Ramasamy [11] also found that residual effect of $\mathrm{ZnSo}_{4}$ gave good seed and haulm yield in blackgram crop in a groundnut-blackgram cropping system and similar findings were reported in residual blackgram in rice-rice-pulse cropping sequence.

Considering the whole cropping system, soil application of Z and B along with NPK increased not only the productivity of maize but also enhanced the yield successive residual blackgram. From this study it is concluded that in maize-blackgram cropping system, application of $\mathrm{ZnSO}_{4}$ and Borax @ $50 \mathrm{~kg}$ and $10 \mathrm{~kg} \mathrm{ha}^{-1}$ along with 100\% recommended NPK increased the successive blackgram yield considerably in zinc and boron deficient soils. 


\section{References}

1. Chandrapala A G, Yakadri M et al. (2010). Productivity and economics of rice (Oryza sativa) - (Zea mays) as influenced by methods of crop establishment, $\mathrm{Zn}$ and $\mathrm{S}$ application in rice, Indian Journal of Agronomy, vol 55(3), 171-176.

2. Goldberg S (2007). New advances in boron soil chemistry, 33-330.

3. Hafeez Z, Khanif Y M et al. (2013). Role of Zinc in plant nutrition-A Review-American Journal of Experimental Agriculture, vol 3(2), 374-391.

4. Katyal J C (2004). Research achievements of an India Co-ordinated Scheme of micronutrients in soils and plants, Fertilizer News, vol 27(2), 67-86.

5. Malakouti M J (2008). The Effect of micronutrients in ensuring efficient use of macronutrients, Turkish Journal of Agriculture and Forestry, vol 32, 215-220.
6. Patel C K, Chaudhari P P et al. (2010). Integrated nutrients management in potato based cropping systems in north Gujarat, Potato Journal, vol 37(1-2), 68-70.

7. Poongothai S, and Chitdeshwari T (2003). Response of blackgram to multi micro nutrients, The Madras Agricultural Journal, vol 90(7-9), 442-443.

8. Singh M V, and Behera S K (2011). AICRP on micro and secondary nutrients and pollutants elements in soils and plants, A Profile, Research Bulletin 10, IISS, Bhopal, 1-57.

9. Shukla Aravind K (2011). Micronutrient Research in India: Current Status and Future Strategies, Indian Society of Soil Science, vol 59, S88-S98.

10. Subramanian K S, Poongothai S et al. (2005). Nutritional and yield response of blackgram to multi micronutrients in Western Agro Ecological Zone of Tamil Nadu, Crop Research, vol 29(3), 406-410.

11. Sudarsan S, and Ramasami P P (1993). Fertilizer News, vol $38,51-53$ 